\title{
CORPORATE GOVERNANCE
}

Luigi Zingales

Working Paper 6309 
NBER WORKING PAPER SERIES

\title{
CORPORATE GOVERNANCE
}

\author{
Luigi Zingales
}

Working Paper 6309

http://www.nber.org/papers/w6309

\section{NATIONAL BUREAU OF ECONOMIC RESEARCH 1050 Massachusetts Avenue Cambridge, MA 02138 \\ December 1997}

My views on this topic have been greatly influenced by my joint work with Raghu Rajan, Walter Novaes, and Lucian Bebchuk. I also benefitted from conversations with (comments of) Renee Adams, Fabrizio Barca, Margaret Blair, Lucian Bebchuk, Darin Clay, Francesca Cornelli, Leonardo Felli, Rob Gertner, Oliver Hart, Henry Hansmann, David Hirshleifer, Randy Kroszner, Jonathan Macy, Peter Newman, Raghu Rajan, David Scharfstein, Andrei Shleifer, Peer Stromberg, Jean Tirole. This project is supported by the NSF grant \#SBR-9423645 and the Center for Research on Security Prices at the University of Chicago. Any opinions expressed are those of the author and not those of the National Bureau of Economic Research.

(C) 1997 by Luigi Zingales. All rights reserved. Short sections of text, not to exceed two paragraphs, may be quoted without explicit permission provided that full credit, including $\mathbb{C}$ notice, is given to the source. 
Corporate Governance

Luigi Zingales

NBER Working Paper No. 6309

December 1997

JEL No. G3

\begin{abstract}
This essay summarizes my own personal view of what corporate governance is about. I argue that it makes sense to discuss corporate governance only in an incomplete contract world. In this world, the notion of corporate governance is intrinsically related to the definition of the firm. In this respect, I review the shortcomings of the existing definitions of the firm and the possible applications of the idea that the firm is a "nexus of specific investments" introduced by Rajan and Zingales (1997a and 1997b). I conclude discussing the limitations of the incomplete contracts approach to corporate governance.
\end{abstract}

Luigi Zinagles

Graduate School of Business

The University of Chicago

1101 E 58th Street

Chicago, IL 60637

and NBER

luigi@gsblgz.uchicago.edu

hhtp://gsblgz.uchicago.edu 


\title{
Corporate Governance
}

\author{
forthcoming in
}

\section{The New Palgrave Dictionary of Economics and the Law}

\author{
Luigi Zingales* \\ University of Chicago, NBER \& CEPR
}

First Draft: August 31, 1997

This Draft: October 31, 1997

While some of the questions have been around since Berle and Means (1932), the term "corporate governance" did not exist in the English language until twenty years ago. In the last two decades, however, corporate governance issues have become important not only in the academic literature, but also in public policy debates. During this period, corporate governance has been identified with takeovers, financial restructuring, and institutional investors' activism. But what exactly is corporate governance? Why is there a corporate governance "problem"? Why does Adam Smith's invisible hand not automatically provide a solution? What role do takeovers, financial restructuring, and institutional investors play in a corporate governance system?

In this essay I will try to provide a systematic answer to these questions, making explicit the essential link between corporate governance and the theory of the firm. My goal is to provide a common framework that helps analyze the results obtained in these two fields and

*My views on this topic have been greatly influenced by my joint work with Raghu Rajan, Walter Novaes, and Lucian Bebchuk. I also benefitted from conversations with (comments of) Renee Adams, Fabrizio Barca, Margaret Blair, Lucian Bebchuk, Darin Clay, Francesca Cornelli, Leonardo Felli, Rob Gertner, Oliver Hart, Henry Hansmann, David Hirshleifer, Randy Kroszner, Jonatahn Macy, Peter Newman, Raghu Rajan, David Scharfstein, Andrei Shleifer, Peer Stromberg, Jean Tirole. This project is supported by the NSF grant \#SBR9423645 and the Center for Research on Security Prices at the University of Chicago. 
identify the questions left unanswered. This is not a survey, so I make no attempt to be comprehensive. For an excellent survey on the topic the reader is referred to Shleifer and Vishny (1997).

\section{When do we need a governance system?}

The word "governance" is synonymous with the exercise of authority, direction, and control. These words, however, seem strange when used in the context of a free-market economy. Why do we need any form of authority? Isn't the market responsible for allocating all resources efficiently without the intervention of authority? The basic (neoclassical) undergraduate microeconomics courses rarely mention the words "authority" and "control."

In fact, neoclassical microeconomics describes well only one set of transactions, which Williamson (1985) calls "standardized." Consider, for instance, the purchase of a commodity, like wheat. There are many producers of the same quality of wheat and many potential customers. In this context, Adam Smith's invisible hand ensures that the good is provided efficiently without the need of any form of authority.

Many daily transactions, however, do not fit this simple example. Consider for instance the purchase of a customized machine. The buyer must contact a manufacturer and agree upon the specifications and the final price. Unlike the case of the wheat, the signing of the agreement does not represent the end of the relationship between the buyer and the seller. Producing the machine requires some time. During this time many events can occur, which alter the cost of producing the machine as well as the buyer's willingness to pay for it. More importantly, before the agreement was signed, the market for manufacturers was competitive. Once production has begun, though, the buyer and the seller are trapped in a situation of bilateral monopoly. The customized machine probably has a higher value to the buyer than to the market. On the other hand, the contracted manufacturer has probably the lowest cost to finish the machine. The difference between what the two parties generate together and what they can obtain in the marketplace represents a quasi-rent, which needs to be divided ex-post. In dividing this surplus Adam Smith's invisible hand is of no help, while authority does play a role. 
In the spirit of Williamson (1985), I define a governance system as the complex set of constraints that shape the ex-post bargaining over the quasi-rents generated in the course of a relationship. A main role in this system is certainly played by the initial contract. But the contract, most likely, will be incomplete, in the sense that it will not fully specify the division of surplus in every possible contingency (this might be too costly to do or outright impossible because the contingency was unanticipated). This creates an interesting distinction between decisions made ex-ante (when the two parties entered a relationship and irreversible investments were sunk) and ex-post (when the quasi-rent are divided). This contract incompleteness also creates room for bargaining.

The outcome of the bargaining will be affected by several factors besides the initial contract. First, which party has ownership of the machine while it is in the production process. Second, the availability of alternatives: how costly is it for the buyer to delay receiving the new machine; how costly is it for the manufacturer to delay the receipt of the final payment; how much more costly is it to have the job finished by another manufacturer, etc. Finally, a major role in shaping the bargaining outcome is played by the institutional environment. For example: how effective and rapid is law enforcement; what are the professional norms; how quickly and reliably does information about the manufacturer's performance travel across potential clients, etc. All these conditions constitute a governance system.

As illustrated by the machine example, there are two necessary conditions for a governance system to be needed. First, the relationship must generate some quasi-rents. In the absence of quasi-rents, the competitive nature of the market will eliminate any scope for bargaining. Second, the quasi-rents are not perfectly allocated ex-ante. If they were, then there would be no scope for bargaining either.

\section{Corporate governance}

The above definition of governance is quite general. One can talk about the governance of a transaction, of a club, and, in general, of any economic organization. In a narrow sense, corporate governance is simply the governance of a particular organizational form - a corporation.

Yet, the bargaining over the ex-post rents, which I defined as the essence of governance, is 
influenced, but not uniquely affected, by the legal structure used. A corporation, in principle, is just an empty legal shell. What makes a corporation valuable are the claims the legal shell has on an underlying economic entity, which I shall refer to as the firm. While often the legal and the economic entity coincide, this is not always the case.

For this reason, I define corporate governance as the complex set of constraints that shape the ex-post bargaining over the quasi-rents generated by a firm.

To be sure, many problems that fall in the realm of corporate governance can be (and have been) profitably analyzed without necessarily appealing to such a broad definition. Nevertheless, all the governance mechanisms discussed in the literature can be reinterpreted in light of this definition. Allocation of ownership, capital structure, managerial incentive schemes, takeovers, boards of directors, pressure from institutional investors, product market competition, labor market competition, organizational structure, etc., can all be thought of as institutions that affect the process through which quasi-rents are distributed. The contribution of this definition is simply to highlight the link between the way quasi-rents are distributed and the way they are generated. Only by focusing on this link can one answer fundamental questions like who should control the firm.

Of course, this definition of corporate governance raises the age-old question of what a firm is. But this question should be central to corporate governance. Before we can discuss how a firm should be governed, we need to define what a firm is. This question is also important because it helps us identify to what extent, if any, corporate governance is different from the governance of a simple contractual relationship (such as the machine example).

There are two main definitions of the firm available in the literature. The first, introduced by Alchian and Demsetz (1972), is that the firm is a nexus of contracts. According to this definition, there is nothing unique to corporate governance, which is simply a more complex version of standard contractual governance.

The second definition, due to Grossman and Hart (1986) and Hart and Moore (1990) (GHM henceforth), is that the firm is a collection of physical assets that are jointly owned. Ownership matters because confers the right to make decisions in all the contingencies unspecified by the initial contract. On the one hand, this definition has the merit of differentiating between a 
simple contractual relationship and a firm. Since the firm is defined by the non-contractual element (i.e., the allocation of ownership), corporate governance (as opposed to contractual governance) is defined by the effect of this non-contractual element. Not surprisingly, the focus of the corporate governance literature in the last decade has been the allocation of ownership (hence this literature is called the property rights view of the firm). On the other hand, this definition has the drawback of excluding any other stakeholder, other than the owner of physical assets, from being important to our understanding of the firm.

More recently, Rajan and Zingales (1997 and 1998) have proposed a broader definition. They define the firm as a nexus of specific investments: a combination of mutually specialized assets and people. Unlike the nexus of contracts approach, this definition explicitly recognizes that a firm is a complex structure that cannot be instantaneously replicated. Unlike the property rights view, this definition recognizes that all the parties who are mutually specialized belong to the firm, be they workers, suppliers, or customers. While this definition does not necessarily coincide with the legal definition, it does coincide with the economic essence of a firm: a network of specific investments that cannot be replicated by the market.

\section{Incomplete Contracts and Governance}

In an Arrow-Debreu economy it is assumed that agents can costlessly write all state-contingent contracts. As a result, all decisions are made ex-ante and all quasi-rents are allocated ex-ante. Thus, there is no room for governance. More surprisingly, even if we relax the assumption that every state-contingent contract can be written and admit that certain future contingencies are not observable (and thus not contractible), we still find no room for governance as long as one can costlessly write contracts on all future observable variables.

Recall the example of the customized machine, and assume that the manufacturer's effort is unobservable to others and is, therefore, not contractible. The neoclassical approach to this problem is to design a mechanism (hence the name "mechanism design"), contingent on all publicly observable variables, which provides the manufacturer with the best possible incentives to exert effort. Myerson (1979) shows that all optimal mechanisms are equivalent to a revelation (direct) mechanism in which the agent (manufacturer) publicly announces 
his information and receives compensation contingent on his announcement. An important consequence of this result is that, in the mechanism design approach, delegation (giving an agent discretion over certain decisions) is always weakly dominated by a fully centralized mechanism, where all decisions are made ex-ante by the designer. The mechanism design approach reproduces several distinguishing features of an Arrow-Debreu economy: all decisions are made ex-ante and only executed ex-post; as a result, all conflicts are resolved and all rents are allocated ex-ante. This leaves no room for ex-post bargaining. All these features are incompatible with not only my definition of governance, but also with any meaningful (i.e. related to the sense in which this term has been used) definition of governance. This is best illustrated with two examples.

One of the crucial questions in corporate governance is in whose interest should corporate directors act? In the mechanism design approach this question cannot even be raised. All possible future conflicts are resolved ex-ante and the initial contract specifies how directors will behave in any observable state of the world. However, since this question is raised all the time, it must be that all possible conflicts are not resolved ex-ante.

Second, the mechanism design approach avoids renegotiation: the initial contract is designed such that the agents do not want to renegotiate. As a result, the designer wants to make renegotiation as inefficient as possible: this reduces the cost of providing incentives to the agents with no efficiency costs, since renegotiation never occurs in equilibrium (Aghion et al. (1997)). If this result were to be taken seriously, the optimal public policy approach would be to preserve any inefficiency in the system in order to avoid destroying its beneficial incentives ex-ante. In reality, though, the jurisprudential approach is completely different. For example, courts do not support punitive damages that are considered excessive with respect to the issue at stake.

Only in a world where some contracts contingent on future observable variables are costly (or impossible) to write ex-ante, is there room for governance ex-post. Only in such a world, are there quasi-rents that must be divided ex-post and real decisions that must be made. Finally, only in a world of incomplete contracts can we define what a firm is and discuss corporate governance as being different from contractual governance. Not surprisingly, the 
theory of governance is intimately related to the emergence and evolution of the incomplete contracts paradigm.

A fundamental milestone in this evolution is the residual rights of control concept introduced by Grossman and Hart (1986). In a world of incomplete contracts, it is necessary to allocate the right to make ex-post decisions in unspecified contingencies. This residual right is both meaningful and valuable. It is meaningful because it confers the discretion to make decisions ex-post. It is valuable, because this discretion can be used strategically in bargaining over the surplus.

\section{Why Does Corporate Governance Matter?}

By definition, corporate governance matters for distribution of rents, but to what extent does it matter for economic efficiency? There are three main channels through which the conditions that affect the division of quasi-rents also affect the total surplus produced. In presenting these channels I will make a sharp distinction between ex-ante (when specific investments need to be sunk) and ex-post (when quasi-rents are divided) effects, as though the firm lasted just one period. Of course, this is not true in reality because ex-post considerations of one period are mixed with ex-ante considerations for the next period.

\subsection{Ex-ante incentive effects}

The process through which surplus is divided ex-post affects the ex-ante incentives to undertake some actions, which can create or destroy some value, in two main ways.

First, rational agents will not spend the optimal amount of resources in value enhancing activities that are not properly rewarded by the governance system. In fact, one goal in designing a governance system is to motivate those investments that are not properly rewarded in the marketplace. The canonical example of how a change in the governance structure can change the incentives to make a value enhancing relationship-specific investment is the Fisher Body case. In the early 1920s, Fisher Body (an auto body manufacturer) refused to locate its plants close to General Motors' plants (in spite of the obvious efficiency improvement generated by such a move). Locating close to GM would have reduced Fisher Body's ability 
to supply other car manufacturers, which would weaken its bargaining position ex-post and possibly reduce its share of the quasi-rents generated by the relationship with GM (see Klein et al. (1978)). A change in the governance system (the acquisition of Fisher Body by GM) eventually led to the efficient plant location decision. Another famous illustration of the same phenomenon is managerial shirking. A manager will shirk if her ex-post bargaining payoff does not increase sufficiently with her effort and, therefore, fails to compensate her for the cost of this effort.

Second, rational agents will spend resources in inefficient activities, whose only (or main) purpose is to alter the outcome of the ex-post bargaining in their favor. For example, a manager may specialize the firm in activities she is best at running because this increases her marginal contribution ex-post and, thus, her share of the ex-post rents (Shleifer and Vishny (1989)). Interestingly, this problem is not limited to the top of the hierarchy, but is present throughout. Subordinates, who do not have much decision power, will waste resources trying to capture the benevolence of their powerful superiors (Milgrom, 1988). Even the well-known tendency of managers to overinvest in growth can be interpreted as a manifestation of this problem. Managers like to expand the size of their business because this makes them more important to the value of the firm and, thus, increases the payoff they can extract in the ex-post bargaining.

Of course, a governance system might promote or discourage these activities. For example, Chandler (1966) reports that, under the Durand reign, GM's capital allocation was highly politicized ("a sort of horse trading"). The move to a multidivisional structure, with the resulting increase in divisional managers' autonomy, reduced the managers' payoff from rentseeking. Similarly, Milgrom and Roberts (1990) explain many organizational rules as a way to minimize influence costs. Finally, Rajan et al. (1997) argue that inefficient "power-seeking" is more severe the more a firm's divisions have diverse investment opportunities. Consistent with this claim, they find that the value of a diversified firm is negatively related to the diversity of the investment opportunities of its divisions.

Thus, a governance system affects the incentives to invest or power-seek, altering the marginal payoffs that these actions have in ex-post bargaining. For instance, for an indepen- 
dent Fisher Body, the marginal effect on the bargaining payoff of localizing its plants close to GM is negative, (it reduces the value of its outside options), but is positive for Fisher Body as a unit of GM, which does not have the authority to supply other manufacturers without GM's consent (see Rajan and Zingales, 1998). Thus, a different ownership structure alters the incentives to make specific investments.

\subsection{Inefficient bargaining}

A second channel through which a governance system affects total value is by altering ex-post bargaining efficiency. This is tantamount to saying that the governance system affects the degree to which the assumptions of the Coase Theorem are violated. A governance system, therefore, can affect the degree of information asymmetry between the parties, the level of coordination costs, or the extent to which a party is liquidity constrained.

For example, if control rights are assigned to a large and dispersed set of claimants (like the shareholders of most publicly traded companies), free-rider problems may prevent an efficient action from being undertaken - even if property rights are well defined and perfectly tradable (Grossman and Hart, 1980). Alternatively, the allocation of control rights can affect efficiency by determining the direction in which a compensating transfer must be made. The direction of the transfer matters when one of the parties to the ex-post bargaining is liquidity constrained (Aghion and Bolton, 1992) or when it faces a different opportunity to invest these resources productively rather than in power-seeking activities (Rajan and Zingales (1996)). In both cases an efficient transaction may not be agreed upon. In the first case, because the party that should compensate does not have the resources. In the second case, because the transaction (while efficient per se) may generate such an increase in wasteful power-seeking to more than offset its benefits.

To this standard list of imperfections, Hansmann (1996) adds the divergence of interests among the parties who have control rights. Citing the political economy literature, Hansmann argues that ex-post inefficiency is increasing in the divergence of interests among control hold-

ers. For example, he argues that allocating control to workers is more costly when they differ in their professional skills, hierarchical position, and tenure. While Hansmann does not provide 
a formal model of why this relation occurs, he does provide very compelling evidence that in practice control rights are rarely allocated to parties with conflicting interests. His conjecture is intriguing because there is no well-established general theory of how different governance systems lead to different levels of ex-post inefficiency. There is little doubt, however, that these inefficiencies exist and are important. For example, Wiggins and Libecap (1985) document that an excessively dispersed initial allocation of drilling rights lead to an inefficient method of extracting oil, with estimated losses as big as $50 \%$ of the total value of the reservoir.

\subsection{Risk aversion}

Finally, a governance system might affect the ex-ante value of the total surplus by determining the level and the distribution of risk. If the different parties have different degrees of risk aversion (or different opportunities to diversify or hedge risk), then the efficiency of a governance system is also measured by how effectively it allocates risk to the most risktolerant party. This idea is the cornerstone of Fama and Jensen's (1983a and 1983b) analysis of organizational structure and corporate governance.

Different governance systems can also generate a different amount of risk. Suppose, for instance, that the total amount of surplus generated is constant. It is still possible that the payoff of each party is stochastic, if the governance structure generates a stochastic bargaining outcome. For example, a life insurance contract written in nominal dollars, creates a pure gamble between the policyholders and the insurance company with respect to the future rate of inflation. This additional "governance" risk (in this case created by the contract, in general created by the governance structure) reduces the value of the total surplus, if the parties are risk-averse and cannot diversify away the risk.

In summary, the objectives of a corporate governance system should be: 1) to maximize the incentives for value enhancing investments, while minimizing inefficient power seeking; 2) to minimize inefficiency in ex-post bargaining; 3) to minimize any "governance" risk and allocate the residual risk to the least risk-averse parties. 


\section{Who should control the firm?}

To show the utility of the framework developed thus far, I will use it to address one of the most controversial issues in corporate governance: who should control the firm. In particular, I will analyze it with regard to the first objective of a corporate governance system. For an analysis focused on the second objective the reader is referred to Hansmann (1996) and for an analysis focused on the third to Fama and Jensen (1983a and 1983b).

As far as the first objective is concerned, the allocation of control is important because it affects the division of surplus. By controlling a firm's decisions, a party can ensure itself of more and more valuable options without the collaboration of the other parties. This guarantees the controlling party a larger share of the surplus within the relationship. Thus, in the framework outlined above, the question of who should control the firm can be rephrased as whose investments need more protection in the ex-post bargaining. Again, the answer to this question is indissolubly linked to the underlying theory of the firm.

In the nexus of contracts view, the firm "is just a legal fiction which serves as a focus for the complex process in which the conflicting objectives of individuals ... are brought in equilibrium within a framework of contractual relationship" (Jensen and Meckling, (1976, p. 312). Thus, according to this view each party is fully protected by its contract with the exception of the shareholders, who accept a residual payoff because they possess a comparative advantage in diversifying risk. As a result, shareholders need the protection insured by control.

While widely popular, this explanation is unsatisfactory. The contractual protection provided to the parties involved in the nexus of contracts is only complete if contracts are complete. But if contracts are complete, then the statement that shareholders are in control is meaningless. In fact, in a world of complete contracts all the decisions are made ex-ante, and thus shareholders are no more in control than are the workers: everything is contained in the initial grand contract. Furthermore, as I have already argued in section 3, this conclusion is inconsistent with the existence of a debate on what a company should do.

Alternatively, if contracts are incomplete, then the argument that all other parties are fully protected by their contractual relationships does not automatically follow. In fact, in this context one should ask why shareholders need more protection than other parties to the 
nexus of contracts. I will return to this issue momentarily.

In the property rights view of the firm, the reason why shareholders should be in control is straightforward. Control is allocated so as to maximize the incentives to make humancapital specific investments. The owner of the firm will generally be the worker with the most expropriable investment. In other words, the property rights approach does not deal with outside shareholders and, thus, it applies only to entrepreneurial firms.

Outside of the GHM framework, the typical justification for why shareholders (or more generally the providers of finance) are in control is based on a combination of three arguments. Shareholders need more protection because: 1) their investment is more valuable; 2) other stakeholders can protect their investments better through contracts; 3) other stakeholders have other sources of power ex-post that protect their investments.

Of the three arguments, the first is clearly unfounded. Reviewing the empirical evidence on the return on specialized human capital, Blair (1995) estimates that the quasi-rent generated by specialized human capital are as big as accounting profits, which are likely to overestimate the quasi-rent generated by physical capital. Hence, there is no ground to dismiss human capital investments as second order to financial investments.

The second argument is harder to dismiss. Since we lack a fully satisfactory theory of why contracts are incomplete, we cannot easily argue which contracts are more incomplete. Nevertheless, it is hard to argue that human capital investments are easier to contract than physical capital investments. If there is one contingency that is easily verifiable, it is the provision of funds. Thus, it is not obvious why providers of funds are at a comparative disadvantage.

The most convincing argument is probably the third. As Williamson (1985) puts it, "the suppliers of finance bear a unique relation to the firm: The whole of their investment in the firm is potentially placed at hazard. By contrast, the productive assets (plant and equipment; human capital) of suppliers of raw material, labor, intermediate product, electric power, and the like normally remains in the suppliers' possession." Thus, the other stakeholders have a better outside option in the ex-post bargaining and they do not need the protection ensured via the residual rights of control. 
Even this argument, however, is not fully satisfactory. In fact, it only suggests that the suppliers of finance should have some form of contractual protection, it does not necessarily imply that they should be protected via the residual rights of control.

A satisfactory explanation of why the residual right belongs to the shareholders can only be obtained in a theory of the firm that explicitly accounts for the existence of different stakeholders and models the interaction between contractual (e.g., ownership) and non contractual sources of power (e.g., unique human capital investments). An attempt in this direction is made by Rajan and Zingales (1998).

To understand the argument note that the residual right of control over an asset always increases the share of surplus captured by its owner (who has the opportunity to walk away with the asset), but it does not necessarily increase her marginal incentive to specialize. If, as it is likely, a more specialized asset has less value outside the relationship for which has been specialized, then specialization decreases the owner's outside opportunity and, thus, her share of the quasi-rents. Owning a physical asset, then, makes an agent more reluctant to specialize it. As a result, the residual right of control is best allocated to a group of agents who need to protect their investment against ex-post expropriation, but who have little control on how much the asset is specialized.

Consider now the different members of the specific investments nexus that makes up the firm. Most of the specific investments which form this nexus are in human capital and, therefore, can neither be contracted nor delegated ex-ante. Granting the residual right to any of these members will have a negative effect on their incentive to specialize.

By contrast, since the provision of funds is easily contractible, funds will be provided in the optimal amount as long as their providers receive sufficient surplus ex-post. Thus, allocating the residual rights of control to the providers of funds has the positive effect of granting them enough surplus ex-post, while avoiding the negative effect of reducing their marginal incentives.

Once they have provided funds, however, financial investors might be reluctant to use these funds for very specialized projects, for fear of seeing their share of the return go down. Thus, it is optimal that, while retaining a residual right of control over the assets, the providers of funds delegate the right to specialize the assets to a third party, who does not internalize the 
opportunity loss generated by this specialization. This third party, thus, should not be in the position of a mere agent, who owes a duty of obedience to the principal, but should be granted the independence to act in the interest of the firm (i.e., the whole body of members of the nexus of specific investments), and not only of the shareholders. Blair and Stout (1997) claim that this is the role American corporate law attributes to the board of directors.

In sum, a broader definition of the firm allows us to understand why the residual right of control is allocated to the providers of capital and why its use is mostly delegated to a board of directors.

\section{Normative Analysis}

An interesting, and largely unexplored, application of the incomplete contract approach to corporate governance is the analysis of its normative implications. In a world of complete contracts, such analysis has limited scope. A benevolent social planner would be unable to improve the ex-ante allocation reached by private contracting, because this will achieve the constrained-efficient outcome. Ex-post, the outcome might be inefficient, but that inefficiency is always part of the written contract and needs to be preserved to maintain ex-ante future efficiency. By contrast, in a world of incomplete contracts, there is ample scope to analyze both ex-ante and ex-post efficiency.

First, a privately optimal governance system may not be socially efficient. In fact, a world of incomplete contracts generates some incentives to "arbitrage power" through time. Consider for instance an entrepreneur, who has immense bargaining power today, but anticipates to lose it in the near future. If she could write all the contracts, she could succeed in extracting all the present and future surplus arising from a relationship without any distortion. But if some contracts cannot be written, then the entrepreneur has incentive to distort her choices so as to transfer some of her bargaining power today into the future, enabling her to capture some of the future surplus as well. This is the idea underlying the choice of ownership in Zingales (1995a) and Bebchuk and Zingales (1996), and of the hierarchical structure in Rajan and Zingales (1997). It can also be used to provide a rationale for the existing mandatory rules (see Bebchuk and Zingales (1996)). 
Second, in a world of incomplete contracts one can discuss the welfare effects of different institutions. For example, in a world of complete contracts the type of legal system a country adopts is irrelevant, as long as private contracts are enforced. By contrast, it is at least conceivable that in an incomplete contract world it may have a significant effect. This is intriguing because empirically it has been shown that legal institutions have an effect on the appropriability of quasi-rents by outside investors (Zingales, 1995b), on the way corporate governance is structured (La Porta et al, 1996), and on the amount of external finance raised (La Porta et al, 1997).

Finally, the incomplete contract approach generates a potential role for government intervention ex-post. Unlike in mechanism design approach, in an incomplete contract world ex-post inefficiency is not necessarily desirable ex-ante. Thus, a selective intervention that eliminates ex-post inefficiency, while preserving the distributional consequences sought exante, will improve welfare.

\section{Limitations of the Incomplete Contract Approach}

While the incomplete contracts approach to corporate governance has brought tremendous insights to the corporate governance debate, it has two weaknesses.

First, its predictions for the optimal allocation of ownership are extremely sensitive to what contracts can be written. Consider, for instance, the plant localization problem discussed above. If no contracts can be written, then - according to the property rights approach Fisher Body (who makes the bigger specific investment) should own the asset. However, if General Motors could credibly commit through a contract to buy all its car bodies from Fisher Body (as it did), then giving ownership to Fisher Body will confer it too much power and, thus, it is optimal for General Motors to own the asset (Hart (1989)). Thus, who should have the residual right of control depends crucially upon what the contractible rights are. But this is very difficult to argue on a priori ground without a general theory of why contracts are incomplete (see Maskin and Tirole, 1997).

Second, this approach relies heavily (as does the complete contract approach) on the agents anticipating all future possible contingencies (Hellwig, 1997). This requirement can be reason- 
able when the subject of analysis is a small entrepreneurial firm, but it loses credibility when it is applied to large publicly-held companies formed decades ago. Can we really interpret the capital structure of IBM today as the outcome of the design by Charles Flint (its founder) in 1911 attempting to allocate control optimally? Hart (1995) argues that the "founding father" interpretation is simply a metaphor for the capital structure that a manager will choose under the pressure of the corporate control market. Yet, Novaes and Zingales (1995) show that the two approaches lead to different predictions not only about the level of debt, but also about its sensitivity to the cost of financial distress and taxes. Thus, at the current state of knowledge the ex-ante approach to the capital structure of non entrepreneurial companies lacks theoretical foundations.

\section{Summary and Conclusions}

In this essay I have tried to summarize the results obtained by applying the incomplete contracts approach to corporate governance. In a world where all future observable contingencies can be costlessly contracted upon ex-ante there is no room for governance. By contrast, in an incomplete contracts world, corporate governance can be defined as the set of conditions that shape the ex-post bargaining over the quasi-rents generated by a firm. A governance system has efficiency effects both ex-ante, through its impact on the incentives to make relationshipspecific investments, and ex-post, by altering the conditions under which bargaining takes place. A governance system also affects the level and the distribution of risk.

The incomplete contracts approach has been very successful in explaining the corporate governance of entrepreneurial firms. It can explain how ownership is allocated and how capital structure is chosen. By contrast, it is difficult for this approach to cope with the complexity of large publicly-traded companies. Nevertheless, recent contributions in the area are able to account for some important features of large corporations: the allocation of ownership to the providers of capital who are dispersed and the importance of internal organization.

Many aspects, however, remain to be investigated. First, and foremost, the role of the board of directors. Second, the interaction between the different mechanisms of corporate governance. While we have many models that describe how each mechanism works in isolation, we know 
very little about how they interact. The effects are not obvious. For example, debt and takeovers are generally thought, in isolation, to be two instruments that reduce the amount of quasi-rents appropriated by management. But the use of debt may crowd out the effectiveness of takeovers, increasing rather than decreasing managerial rents (Novaes and Zingales (1995)). Third, the normative implications of this approach deserve more attention. In a world of incomplete contracts, the privately optimal governance can be inefficient ex-ante and ex-post. Of course, this is only a theoretical possibility, whose relevance needs to be assessed in the data. The most important contribution, however, will arise from a development of the underlying theory. Without a better understanding of why contracts are incomplete, all the results are merely provisional. 


\section{References}

Aghion, P. and Bolton, P. 1992. An incomplete contract approach to financial contracting. Review of Economic Studies 59: 473-494.

Aghion, P., Bolton, P., and Felli, L. 1997. Some issues on contract incompleteness. London School of Economics working paper.

Alchian, A. and Demsetz, H. 1972. Production, information costs and economic organization. American Economic Review 62: 777-705.

Berle, A. and Means, G. 1932. The Modern Corporation and Private Property. New York: World Inc.

Blair, M.M. 1995. Ownership and Control. Washington D.C.: The Brookings Institution.

Blair, M.M. and Stout, L. 1997. A theory of corporation law as a response to contracting problems in team production. Brookings Institution Working Paper. http://www.brook.edu

Bebchuk, L. and Zingales, L. 1996. Corporate ownership structure: private versus social optimality. NBER WP \# 5584. http://gsblgz.uchicago.edu.

Chandler, A. 1966. Strategy and Structure. New York: Doubleday \& Co.

Fama, E. and Jensen, M. C. 1983a. Separation of ownership and control. Journal of Law and Economics 26: 301-325.

Fama, E. and Jensen, M. C. 1983b. Agency problems and residual claims. Journal of Law and Economics 26: 327-349.

Grossman, S. and Hart, O. 1980. Takeovers bids, the free rider problems and the theory of the corporation. Bell Journal of Economics 11: 42-69.

Grossman, S. and Hart, O. 1986. The costs and the benefits of ownership: A theory of vertical and lateral integration. Journal of Political Economy 94: 691-719.

Hansmann, H. 1996. The Ownership of Enterprise. Cambrdige MA: Belknap Harvard.

Hart, O. 1989. An economist's perspective on the theory of the firm Columbia Law Review 89: $1757-1774$.

Hart, O. 1995. Firms, Contracts, and Financial Structure Oxford: Oxford University Press.

Hart, O. and Moore, J. 1990. Property rights and the nature of the firm. Journal of Political Economy 98: 1119-1158.

Hellwig, M. 1997. Unternehmensfinanzierung, Unternehmenskontrolle und Ressourcenallokation: Was leistet das Finanzsystem? University of Mannheim. Arbeitspapeier Nr. 97/02. 
Jensen M. C. and Meckling, W. 1976. Theory of the Firm: Managerial Behavior, Agency Costs and Capital Structure. Journal of Financial Economics 3: 305-360.

Klein, B., Crawford R., and Alchian, A. 1978. Vertical integration, appropriable rents and the competitive contracting process. Journal of Law and Economics 21: 297-326.

La Porta, R., Lopez de Silanes, F., Shleifer, A., and Vishny, R. 1996. Law and Finance. NBER Working Paper 5661.

La Porta, R., Lopez de Silanes, F., Shleifer, A., and Vishny, R. 1997. Legal Determinants of External Finance. Journal of Finance 52: 1131-1150.

Maskin, E. and Tirole, J. Unforseen contingencies, property rights, and incomplete contracts. Harvard University working paper.

Milgrom, P. 1988. Employment contracts, influence activities, and efficient organization design. Journal of Political Economy 42: 42-61.

Milgrom, P. and Roberts, J. 1990. Bargaining costs, influence costs, and the organization of economic activity. In Perspectives on Positive Political Economy, eds. J. Alt and K. Shepsle. Cambridge: Cambdrige University Press.

Myerson, R. 1979. Incentive compatibility and the bargaining problem. Econometrica 51: 1767-1797.

Novaes, W. and Zingales, L. 1995. Capital structure choice when managers are in control: Entrenchment versus efficiency. NBER working paper \# 5384. http://gsblgz.uchicago.edu.

Rajan, R., Servaes, H., and Zingales, L. 1997. The cost of diversity: Diversification discount and inefficient investment. University of Chicago working paper. http://gsblgz.uchicago.edu.

Rajan. R. and Zingales, L. 1996. The tyranny of the inefficient: An enquiry into the adverse consequences of power struggles . NBER working paper \# 5396. http://gsblgz.uchicago.edu.

Rajan, R. and Zingales, L. 1997. The firm as a dedicated Hierarchy. University of Chicago working paper. http://gsblgz.uchicago.edu.

Rajan, R. and Zingales, L. 1998. Power in a theory of the firm. Quarterly Journal of Economics. May: forthcoming.

Shleifer, A. and Vishny, R. 1989. Management entrenchment: The case of manager-specific assets. Journal of Financial Economics 25: 123-140.

Shleifer, A. and Vishny, R. 1997. A survey of corporate governance. Journal of Finance 52: 737-783.

Wiggins, S. N. and Libecap, G. D. 1985. Oil field unitization: Contractual failure in the presence of imperfect information. American Economic Review 75: 368-385. 
Williamson, O. 1985. The Economic Institutions of Capitalism. New York, NY: The Free Press.

Zingales, L. 1995a. Insider ownership and the decision to go public. Review of Economic Studies 62: 425-448.

Zingales, L. 1995b. What determines the value of corporate votes? Quarterly Journal of Economics 110: 1047-1073.. 